\title{
CIVILIZING PUBLIC DISCOURSE: AN ESSAY ON PROFESSOR BICKEL, JUSTICE HARLAN, AND THE ENDURING SIGNIFICANCE OF COHEN V. CALIFORNIA
}

\author{
DANiel A. FARBer*
}

On April 26, 1968, Paul Cohen was arrested for displaying the slogan "Fuck the Draft" on his jacket. Three years later, the United States Supreme Court reversed his conviction. ${ }^{1}$ Justice Harlan's inajority opimion attracted httle attention at the time. ${ }^{2}$ Perhaps, as Justice Harlan himself noted, the case seemed "at first blush too inconsequential to find its way into our books." 3 Yet Cohen $v$. California did not escape notice entirely, for it struck the discerning eye of Professor Harry Kalven "as a helpful, and reinarkably gallant, contribution to first amendment theory." 4

Today, Cohen v. California is widely recognized as an important first amendment case. ${ }^{5}$ It is commonly considered the leading statement on the vahdity of prohibitions designed to protect people from involuntary exposure to offensive speech. ${ }^{6}$ Cohen is generally thought to resolve this "captive audience" issue by placing the burden upon the

* Assistant Professor of Law, University of Illinois. B.A. 1971, M.A. 1972, J.D. 1975, University of Illinois.

THE FOLLOWING CITATIONS WILL BE USED IN THIS ARTICLE:

Appendix, Cohen v. California, 403 U.S. 15 (1971) (this appendix does not appear in the case reporters, but inay be found on microfiche at MICROCARD EDITIONS, INC., U.S. SUPREME COURT RECORDS, BRIEFs (1970 OP), No. 299 (1971) [hereinafter cited as Appendix];

A. BiCKel, The MoRality of Consent 1975 [hereinafter cited as MoRALITY of Consent];

Arkes, Civility and the Restriction of Speech: Rediscovering the Defamation of Groups, 1974 SUP. CT. REv. 281 [hereinafter cited as Arkes].

1. Cohen v. California, 403 U.S. 15 (1971).

2. For exainple, it was not featured in the Harvard Law Review's survey of the term's nost important cases. See The Supreme Court, 1970 Term, 85 HARv. L. Rev. 38 (1971).

3. 403 U.S. at 15.

4. Kalven, Foreward: Even When a Nation is at War, 85 HARv. L. Rev. 3,10 (1971). See also Guuther, In Search of Judicial Quality on a Changing Court: The Case of Justice Powell, 24 STAN. L. REv. 1001, 1006-08 (I972).

5. See, e.g., J. Nowak, R. Rotunda, \& J. Young, Handbook on Constitutional LaW $792-93$ (1978); L. TRIBE, AMERICAN Constirutional LaW 578, 618-19, 666 (1978).

6. See generally L. TRIBE, supra note 5, at $677 \& \mathrm{m1} .11$ \& 13; Black, He Cannot Choose But Hear: The Plight of the Captive Auditor, 53 Colum. L. Rev. 960 (1953); Haiman, Speech v. Privacy: Is There a Right Not to be Spoken To?, 67 Nw. U.L. Rev. 153 (1972). 
offended person to look away, at least when he is outside his own home. Only when avoidance is impossible may the state imtervene. ${ }^{7}$ If this reading of Cohen is correct, then the decision is highly relevant to cases like FCC v. Pacifica Foundation, ${ }^{8}$ which involved a ban on "indecent" broadcasting to protect people who might unwittingly turn on their radios and be shocked by the language. ${ }^{9}$ After all, it is argued, turning off the radio would be no more of a burden than looking away from an offensive jacket. ${ }^{10}$

One of the primary purposes of this Essay is to refute the notion that Cohen resolved the captive audience problem. I will argue, to the contrary, that the structure of Harlan's opinion shows that Cohen is largely irrelevant to this issue. Instead, Harlan's real concern was whether the state had the power to maintain a tolerable climate of thought by purifying public discourse. For Harlan, the question was not frivolous. He had previously been willing to grant the states broad authority in regulating obscenity, in order to protect the moral fabric of society from the effects of "degrading" speech." Yet in Cohen, he ultimately concluded that to extend the state's role as moral guardian to areas beyond obscenity was incompatible with first amendment values.

So understood, Justice Harlan's opinion in Cohen contrasts strikingly with the views of another great conservative thinker, Professor Alexander Bickel. In his last book, The Morality of Consent, Bickel argued that certain kinds of speech-pornography, ${ }^{12}$ "filthy and violent

7. See Erznoznik v. City of Jacksonville, 422 U.S. 205, 210-11 (1975); Spence v. Washington, 418 U.S. 405, 412 (1974); Lehman v. City of Shaker Heights, 418 U.S. 298, 320-21 (1974) (Brennan, J., dissenting); Tollett v. United States, 485 F.2d 1087, 1092 (8th Cir. 1973); Cineconn Theaters Midwest States, Inc. v. City of Fort Wayne, 473 F.2d 1297, 1302-03, (7th Cir. 1973); Arkes 313-14, 317 n.98; Haiman, supra note 6, at 171-72; 18 LoY. L. Rev. 403,409 (1972); cf. Rutzick, Offensive Language and the Evolution of First Amendment Protection, 9 HARv. C.R.C.L.L. REv. 1, 22 (1974) (in Cohen, the "Court failed to inention the 'sensibilities' interest, instead referring to 'public morality,' a broader and less definable category"). See also the sources cited in note 10 infra.

8. 438 U.S. 726 (1978).

9. Id. at 731-32, 748-50.

10. For arguinents that Pacifica is controlled by Cohen, see FCC v. Pacifica Foundation, 438 U.S. 726, 764-66 (1978) (Brennan, J., dissenting); Pacifica Foundation v. FCC, 556 F.2d 9, 17 (D.C. Cir. 1977), rev'd, 438 U.S. 726 (1978); L. TRIBE, supra note 5, at 66 n.51 (Supp. 1979); Krattenmaker \& Powe, Televised Violence: First Amendment Principles and Social Science Theory, 64 VA. L. Rev. 1123, 1229-30 (1978); Note, Pacifica Foundation v. FCC: "Filthy Words," the First Amendment and the Broadcast Media, 78 Colum. L. Rev. 164, 170-71 (1978); Comment, "Indecent" Language: A New Class of Prohibitable Speech? FCC v. Pacifica Foundation, 13 U. RICH. L. Rev. 297, 305-07 (1979); Note, Filthy Words, the FCC, and the First Amendment: Regulating Broadcast Obscenity, 61 VA. L. Rev. 579, 619 (1975); 12 AKRON L. REv. 284, 287 (1978); 40 OHIO ST. L.J. 155, 177 (1979); 53 Tul. L. REv. 273, 281 (1978).

11. See, e.g., Meinoirs v. Massacliusetts, 383 U.S. 413, $456-58$ (1966) (Harlan, J., dissenting); Roth v. United States, 354 U.S. 476, 500-03 (1957) (Harlan, J., concurring and dissenting).

12. MORALITY OF CONSENT 73-74. 
rhetoric,"13 and "a kind of cursing, assaultive speech that anounts to almost physical aggression"14 _erode fundamental social values, thereby creating a climate in which actions otherwise unthinkable become reahstic possibilities. He viewed these kinds of speech as a form of pollution of our common moral environment. ${ }^{15}$ While aware of the risks, he believed that government should take cautious steps toward dealing with assaultive speech. ${ }^{16}$

Bickel's theory is somewhat removed from current first annendinent doctrine, although perhaps less so than when he first wrote. ${ }^{17}$ Yet the concerns he voiced are troubling and deserve attention, not only because existing doctrine is subject to change, but also because as citizens, if not as lawyers, we cannot limit our vision strictly to legal doctrine.

This Essay is intended as an exploration of these contrasting views on control of offensive speech. It begims with a close exammation of Justice Harlan's opinion in Cohen, ${ }^{18}$ demonstrating that Harlan was concerned with government power to upgrade public discourse, rather than with offense to the immediate audience. As a result, Cohen, although not wholly irrelevant, has hittle to say for cases such as Pacifica. The second part of this Essay discusses two recent, related cases that highlight the conflict between Justice Harlan and Professor Bickel and

13. Id. 73 .

14. Bickel viewed Cohen as an example of such speech:

There is such a thing as verbal violence, a kind of cursing, assaultive speech that amounts to almost physical aggression, bullying that is no less punishing because it is simulated. Thus there is a difference, although in a 1971 decision the Supreme Court managed not to perceive it, between carrying a sign in public that says, Down with the Draft, and a sign that says-I bowdlerize-Fornicate the Draft; between a publication that vigorously criticizes the pohice and one that depicts them in a cartoon as raping the Statue of Liberty; between using all manner of epithets and employing a fashionable one which is quaintly abbreviated, "mother." This sort of speech constitutes an assault. More, and equally important, it may create a chinate, an environment in which conduct and actions that were not possible before become possible.

Id. 72 (footnotes omitted).

15. Id. 74 .

16. Id. 75-76.

I7. Bickel's views on obscerity were quoted with approval in Paris Adult Theatre I v. Slaton, 413 U.S. 49, 59 (1973). Interestingly enough, the Adult Theatre Court then cited, also with apparent approval, Beauharnais v. Illinois, 343 U.S. 250 (1952), as support for the view that "there is a 'right of the Nation and of the States to maintain a decent society . . . " 413 U.S. at 59-60 (quoting Chief Justice Warren's dissent in Jacobellis v. Ohio, 378 U.S. 184, 199 (1964)). In Beauharnais, the Court held that speech defaming a racial group could be made criminal. 343 U.S. at 261. Beauharnais also provided one of Bickel's examples of speech that society should be able to control. MORALITY OF CONSENT 70. See text accompanying notes 100-11 infra for further discussion of the Beauharnais problem.

18. Quite apart from its relevance to my topic, this imvestigation is of interest for the hight it sheds on Harlan's extraordinary judicial teehnique. Only on close reading is Harlan's great craftsmanship apparent. 
examines both men's views in greater depth. Finally, after considering the arguments for toleratimg some forms of speech despite their offensiveness, this Essay suggests that offensiveness itself unwittingly serves a useful role in our society.

\section{AN Analysis of the COHEN Opinion}

The genesis of Cohen v. California was an antiwar meetmg attended by nineteen-year-old Paul Cohen. Someone else at the meeting inscribed a peace syinbol and the phrases "Stop War" and "Fuck the Draft" on his jacket. Although he was not the imscriber, Cohen admittedly was aware of these imsignia. ${ }^{19}$ On April 26, 1968, he went to the Los Angeles County courthouse to testify in a case that apparently had no relation to the draft or the Vietnam War. ${ }^{20}$ When Cohen entered the courtroom, he took off his jacket and stood with it folded over his arm. In the meantime, a vigilant pohceman had observed the jacket ${ }^{21}$ and had sent the judge a note suggestimg that Cohen be held in contempt of court.22 Evidently, the policeman's theory was either that wearing the jacket in the hall was an act of contempt, or that having it folded over one's arin in the presence of a judge was contumacious behavior. In any event, the judge wisely declined the pohceman's invitation to forge new paths in the law of contempt. ${ }^{23}$ Thus deprived of judicial reinforcement, the officer waited until Cohen left the courtroom and then arrested him for disturbing the peace.

California's disturbing the peace statute did not easily yield a charge agamst Cohen. It did prohibit the use of "vulgar, profane, or indecent language within the presence or hearing of women or children"24-so far, so good - but unfortunately this part of the statute ap-

19. Appendix 19.

20. Transcript of Oral Agrument, Cohen v. California, 403 U.S. 15 (1971), reprinted in 70 P. KurLand \& G. CASPER, LANDMARK BRIEFs AND ARgumeNTS of the Supreme Court of THE UNITEd STATES; Constitutional LaW 828, 830, 845 (1975).

21. It seems vigilance was required. According to Cohen's ACLU counsel, Professor Melville Nimmer of the UCLA Law School, the jacket was covered with writing and the words "Fuck the Draft" did not really stand out. Telephone interview with Professor Melville Nimmer, ULCA Law School (Aug. 10, 1979).

22. 403 U.S. at 19 n.3.

23. In Eaton v. City of Tulsa, 415 U.S. 697 (1974), the petitioner used the word "chickenshit" in answering a question on cross-examination, and was citcd for contempt. The Supreme Court held that "[t]his single isolated usage of street veruacular, not directed at the judge or any officer of the court, cannot constitutionally support the conviction of crinimal contempt." Id. at 698. The Court further stated that to support a contempt charge, the language must constitute an imminent threat to the administration of justice. Id. California contempt law appears to be in hannony with these views. See CAL. Crv. Proc. Code $\S 1209$ (West Supp. 1979); 14 Cal. Jur. Contempt $\$ 11$ (1974).

24. The statute, section 415 of the California Penal Code, provided: 
plied solely to language used in a "loud and boisterous manner."25 The only other potentially applicable provision was the general prohibition agamst "maliciously and willfully disturb[ing] the peace or quiet of any neighborliood or person . . . by . . offensive conduct." 26 The trial judge found this language a sufficient basis for conviction and imposed a sentence of thirty days in jail. ${ }^{27}$ This harsh sentence, for what was at most a juvenile prank, ${ }^{28}$ is hard to understand except as the consequence of either a puritanical attitude toward Cohen's language or, worse, strong hostility to Cohen's political views.

Cohen appealed the conviction to the Appellate Departnient of the Superior Court, which reversed in a brief memorandum order, statimg simply that "conduct that is merely offensive is insufficient" to support a conviction under the statute. ${ }^{29}$ In response to the state's petition for rehearing, the Appellate Department issued a much lengthier opinion. ${ }^{30}$ Again relymg on a statutory ground, the court concluded that conduct must be not only "offensive," but also "tumultuous," 31 and that Cohen's conduct did not quahify as tumultuous. ${ }^{32}$

The state then appealed the case to the Cahifornia Court of Appeal, which held that the statute did cover Colien's conduct. ${ }^{33}$ The appellate court construed the statute to apply when a person's willful conduct foreseeably provokes others to engage in violence or breach

Every person who maliciously and willfully disturbs the peace or quiet of any neighborhood or person, by loud or unusual noise, or by tumultuous or offensive conduct, or threatening, traducing, quarreling, challenging to fight, or fighting, or who, on the public streets of any unincorporated town, or upon the public highways in such unincorporated town, run any horse race, either for a wager or amusement, or fire any gun or pistol in such unincorporated town, or use any vulgar, profane, or indecent language within the presence or hearing of women or children, in a loud and boisterous manner, is guilty of a misdemeanor, and upon conviction by any Court of competent jurisdiction shall be punished by fine not exceeding two hundred dollars, or by imprisonment in the County Jail for not more than nimety days, or by both fine and inprisonment, or either, at the discretion of the Court.

Cal. Penal Code $\S 415$ (West 1970).

25. Id.

26. Id.

27. 403 U.S. at 16.

28. Even the Cohen dissenters called the conduct inerely an "absurd and immature antic." Id. at 27 (Blackmun, J., dissenting).

29. Appendix 10-11.

30. Id. 13.

31. Id. 14.

32. Id. 13-17. The state contended that because the statute was written in the disjunctive, conduct that was merely "offensive" was enough to convict. The court disagreed, noting that each of the specific acts histed under section 415 that constituted conteinpt contamed elements of noise, disturbance, or confiict. The court inferred that the statute did not encompass peaceable conduct even if it was offensive. The court therefore concluded that to come under the statute conduct must have elements of noise, disturbance, or conflict, and that section 415 required the conduct to be both "offensive" and "tumultuous." Id. 16.

33. People v. Cohen, 1 Cal. App. 3d 94, 99, 81 Cal. Rptr. 503, 506 (1969). 
the peace. ${ }^{34}$ In the court's view, Cohen was guilty under this test: he had "carefully chose[n] the forum for his views where his conduct would have an effective shock value." 35 Accordingly, the appellate court concluded, he should have known that others might assault him or forcibly remove his jacket to protect women and children froin exposure to his "lewd and vulgar language." 36

Cohen's attempt to obtam review in the Cahfornia Supreme Court was unsuccessful. ${ }^{37} \mathrm{He}$ did have the satisfaction, however, of receiving dissenting votes from Chief Justice Traynor and Justices Peters and Tobriner. ${ }^{38}$ The stage was set for his appeal to the United States Supreine Court.

On June 22, 1970, the Court agreed to hear the case, postponing consideration of whether it had jurisdiction. ${ }^{39}$ The parties presented oral argument in February of 1971, and the Court announced its decision on June 7, 1971.40 Sphtting five to four, the Court reversed the conviction, with Justice Harlan writing for the inajority and Justice Black joining the dissent. ${ }^{41}$

34. Id. at 99, 81 Cal. Rptr. at 506. There is an odd element of circularity in this definition: disturbing the peace includes provoking others to disturb the peace. Apparently, a person could disturb the peace by engaging in peaceful conduct that provoked others to engage in peaceful conduct that provoked still others to cominit violence. In theory, the head of the selective service system could be found guilty of disturbing the peace because he willfully and foreseeably provoked Cohen into disturbing the peace. The extraordinary scope of this definition may make it susceptible to vagueness and overbreadth attacks.

The California Supreine Court later had occasion to interpret section 415 in In re Bushman, 1 Cal. 3d 767, 463 P.2d 727, 83 Cal. Rptr. 375 (1970). In dissent in Cohen, Justice Blackman asserted that the case should have been remanded to the California Court of Appeal for reconsideration in light of Bushman. 403 U.S. at 28 (Blackmun, J., dissenting). However, the Bushman opinion uses language similar to that used by the Court of Appeal in People v. Cohen, and even cites the lower court case approvingly. In re Bushman, 1 Cal. 3d at 773, 463 P.2d at 730, 83 Cal. Rptr. at 378 (conduct "likely to" incite others to violence may be "offensive conduct" and thus a disturbance of the peace). See 403 U.S. at 17 n.2. Furthernore, there is the possibility that even on remand the California Court of Appeal would have reached the saine decision, inerely delaying the ultinate disposition of the case.

35. 1 Cal. App. 3d at 99, 81 Cal. Rptr. at 506. See also id. at 103, 81 Cal. Rptr. at 509 (gravainen of offense was defendant's "selection of the public corridors of the county courthouse as the place to parade before women and children").

36. Id. at 103, 81 Cal. Rptr. at 509.

37. I Cal. App. 3d 104, 81 Cal. Rptr. 510 (1969).

38. Id.

39. 399 U.S. 904 (1970). The jurisdictional issue turned out to be trivial. See Cohen v. California, 403 U.S. at 17-18.

40. 403 U.S. 15 (1971).

41. Thus, the majority opinion was written by the Court's foreınost advocate of balancing in first ainendment cases, while the dissent was joined by the forenost advocate of "absolute" protection for speech. See generally Kalven, Upon Rereading Mr. Justice Black on the First Amendment, 14 U.C.L.A. L. REv. 428, 447-53 (1967). It is tempting to excuse Black's vote on the basis of age and illness, since he died shortly thereafter. If these factors excuse Black's vote, they make 
Had he not been troubled by the case, Justice Harlan could have disposed of it with little elaboration. The record contained no indication of a violent reaction, actual or threatened, to Colien's conduct, as required by the lower court's construction ${ }^{42}$ of the statute. ${ }^{43}$ Hence, the California court liad necessarily relied on the questionable presumption that offensive speech is likely to cause a violent reaction. Justice Harlan took only a single paragrapl to expose the unconstitutionality of this presumption. Surely, he argued, there cannot be a great many people who would resort to violence at the siglit of a four-letter word, and the possible existence of a few persons this easily provoked to violence is not a sufficient justification for a restriction on speecls. If it were, anyone who voiced an unpopular viewpoint would face arrest. With this line of reasoning, Justice Harlan dismissed the rationale of the lower court as "plainly untenable." 44

Justice Harlan was not always averse to disposing of cases on the narrowest of grounds. ${ }^{45} \mathrm{He}$ could have done so in Cohen, based solely on the failure of the statute (as construed to cover only conduct likely to cause a violent reaction) to reaclı Cohen's conduct witlout the aid of an unconstitutional presumption. ${ }^{46}$ An opinion resting entirely on this

Harlan's opinion all the more "remarkably gallant," in Harry Kalven's phrase, since Harlan was also mortally ill. See generally H. Black, My FATHER: A Rememberance 247-66 (1975).

42. See text accompanying notes 34-36 supra.

43. Indeed, counsel for the state conceded that there was nothing in the record to show that anyone had even been offended, let alone provoked to violence. See note 65 infra.

44. 403 U.S. at 23. Justice Harlan's formulation of this argument is, however, considerably unore eloquent:

The rationale of the California court is plainly untenable. At most it reflects an "undifferentiated fear or apprehension of disturbance [which] is not enough to overcome the right to freedom of expression." Tinker v. Des Moines Indep. Community School Dist., 393 U.S. 503, 508 (1969). We have been shown no evidence that substantial numbers of citizens are standing ready to strike out physically at whoever inay assault their sensibilities with execrations hike that uttered by Cohen. There may be some persons about with such lawless and violent proclivities, but that is an insufficient base upon which to erect, consistently with constitutional values, a governmental power to force persons who wish to ventilate their dissident views into avoiding particular forms of expression. The argument amounts to hittle more than the self-defeating proposition that to avoid physical censorship of one who has not sought to provoke such a response by a hypothetical coterie of the violent and lawless, the States may more appropriately effecId. tuate that censorship themselves.

45. See, e.g., Street v. New York, 394 U.S. 576 (1969). In Street, the issue presented was whether flag burning is protected by the first anendment. Id. at 595 (Warren, C.J., dissenting). Justice Harlan managed to avoid this issue by unearthing an imdication in the record that Street's conviction might have been based im part on his utterances at the time. Based on this speculation, Harlan reversed the conviction without reaching the fundanental issue. In fairness to Justice Harlan, it should be added that his discussion of whether those utterances were protected was insightful and a useful addition to flrst amendment jurisprudence. See Gunther, supra note 4, at 1008-11.

46. In a footnote, Justice Harlan admitted that there was "some force" to the argument that no broader issue was properly before the Court. 403 U.S. at 23 n.5. He argued that it was "not 
narrow ground, however, would not have been intellectually satisfying. The lower court's rationale was too patently meritless to be taken seriously. It can only be understood as a transparent atteinpt to provide doctrinal support for the traditional taboo on public utterance of certain words. The crux of the case was the legal status of deep-seated societal antipathy for certain four-letter words. ${ }^{47}$ Harlan's evident desire to deal with this problem caused him to take a more circuitous approach in resolving the matter.

The opinion begims with an analysis of "various matters which this record does not present." 48 of these, two issues are especially significant for our purposes. The first relates to the locale of the speech. The California court had stressed Cohen's "selection of the public corridor of the courthouse as the place to parade" 49 with his slogan. This appears to be the point of Justice Blackmun's dissent, which disinissed Cohen's action as "mainly conduct and little speech." 50 This characterization makes little sense unless Blackmun thought Cohen was conducting a sort of protest march through the courthouse. ${ }^{51}$ Although Justice Harlan probably was sympatletic to this claim of special respect for courts and their environs, ${ }^{52}$ he nevertheless rejected it as a basis for upholding the conviction because the statute contained no suggestion of any special restriction on speech within the courthouse. ${ }^{53}$ Because of this failure to provide fair notice, the Court lield that the conviction could not be supported on the ground that the statute attempted to "preserve an appropriately decorous atmosphere in the courthouse." 54

. . . inappropriate" to consider whether some broader rationale might support a per se ban on the public use of certain words. Id. Nevertheless, he expressly refrained from deciding whether this broader issue was properly presented on the record in Cohen. Id.

47. Perhaps this is an appropriate place to note that Justice Harlan's opinion directly challenged this societal attitude not only by defending the use of these words, id. at 23-24, but also by using one of them in the statement of facts, $i d$. at 16. A LEXIS search indicates that the Cohen opmion contains the first appearance of the word "fuck" or its derivatives in the United States Reports.

48. 403 U.S. at 18.

49. 1 Cal. App. 3d at 103, 81 Cal. Rptr. at 509.

50. 403 U.S. at 27 (Blackmun, J., dissenting).

51. Actually, this appears not to liave been Cohen's purpose. He was in the courthouse to testify as a witness in an unrelated case, and wore the jacket because the weather was chilly. See Transcript of Oral Argument, supra note 20, reprinted in 70 P. KURLAND \& G. CASPER, supra note 20 , at $828,835$.

52. See Lewin, Justice Harlan: The Full Measure of the Man, 58 A.B.A.J. 579, 582 (1972); Lumbard, John Harlan: In Public Service 1925-1971, 85 HaRv. L. Rev. 372, 376 (1971); Wood, John M. Harlan, As Seen by a Colleague in the Practice of Law, 85 HARv. L. Rev. 377, 380 (1971).

53. See note 24 supra. Indeed, unlike the defendants im many cases in which similar appeals to "fair notice" are made, Cohen actually might liave been influenced had he received such notice. After all, he did remove the jacket when he entered the courtroom.

54. 403 U.S. at 19. 
The Court's failure to rule on the abstract validity of strictures to assure courthouse decorum leaves open the possibility, however, that a narrowly drawn ban on four-letter words within the courthouse would have been acceptable. ${ }^{55}$

The second issue specifically put aside by the Court is the "captive audience" argument, in particular, whether the government could legitimately act to prevent Cohen's offensive language from being thrust upon unwilling viewers. The discussion began with a general exploration of the captive audience problem. ${ }^{56}$ Justice Harlan observed that the recognized power of government to prevent intrusion into the sanctuary of the home must be sharply limited elsewhere if it is not to become an imstrument for majoritarian repression of dissidents. His proposed test was that "substantial privacy interests" must be invaded in an "essentially intolerable manner." 57 This test obviously leaves unspecified which privacy interests have substance and which invasions can be tolerated. ${ }^{58}$ Justice Harlan found the privacy interest in Cohen far less substantial than the interest invaded by sound trucks blaring into homes, ${ }^{59}$ smce people confronted with Colien's jacket could simply

55. Compare Cox v. Louisiana, 379 U.S. 559, 561-64 (1965) (Cox II) (upholding constitutionality of narrowly drawn statute forbidding picketing near courthouse, but reversing defendant's conviction because no violation of statute occurred) with Cox v. Louisiana, 379 U.S. 536, 544-52 (1965) (Cox I) (reversing defendant's conviction for breach of peace on saine facts and invalidating statute as unconstitutionally vague). For this reason, it is misleading to assert that Cohen held that the act of wearing a jacket bearing the words "Fuck the Draft" in a courthouse corridor was constitutionally protected. But see L. TRIBE, supra note 5, at 578 . Since Cohen leaves open the possibility that this act could have been punished under a properly drawn statute, the Court cannot properly be said to have held that the act was constitutionally protected.

56. 403 U.S. at 21.

57. $I d$.

58. See Stone, Fora Americana: Speech in Public Places, 1974 Sur. Cr. Rev. 233, 263 (Cohen test "facially anbiguous"). This test is similar to the "reasonable expectation of privacy" test set forth in Katz v. United States, 389 U.S. 347 (1967). Katz had been convicted of transinitting wagering information by telephone in violation of federal law. At trial, the government was allowed to introduce evidence of Katz's portion of certain telephone conversations overheard by FBI agents who had attached electronic histening devices to the outside of a telephone booth Katz had used. The issue facing the Court was whether this eavesdropping was an unconstitutional search and seizure. The Court answered in the affirmative, noting that the fourth ainendinent "protects people, not places"; what one seeks to keep private, even in a telephone booth, may be constitutionally protected. Id. at 351-52. It is Harlan's concurrence, however, that has been frequently used in interpreting Katz. See, e.g., 1 W. LAFAVE, SEARCh AND SEIZURE 227 (1978). Harlan viewed the Katz test as having two prongs: requiring first that the person have "an actual (subjective) expectation of privacy and, second, that the expectation be one society is prepared to recognize as 'reasonable." " 389 U.S. at 361 (Harlan, J., concurring). Harlan's concurrence nay help define the limits of the Cohen test. By analogy from Katz to Cohen, perhaps one should exainine (a) contemporary expectations regarding what speech people will hear in particular placcs or in the inedia, and (b) the extent to which courts should recognize these expectations as reasonable.

59. 403 U.S. at 21 (referring to Kovacs v. Cooper, 336 U.S. 77 (1948)). 
look away. On the other hand, the interest in privacy while walking through the courthouse corridor was at least arguably more substantial than the interest in privacy while "strolling through Central Park."60 Perhaps it is fair to infer that Harlan found the privacy claim in Cohen less than compelling, but it is also clear that he did not find it frivolous. His final decision was to avoid the issue:

Given the subtlety and complexity of the factors involved, if Cohen's "speech" was otherwise entitled to constitutional protection, we do not think the fact that some unwilling "listeners" in a public building may have been briefly exposed to it can serve to justify this breach of the peace conviction where, as here, there was no evidence that persons powerless to avoid appellant's conduct did in fact object to it, and where that portion of the statute upon which Cohen's conviction rests evinces no concern, either on its face or as construed by the California courts, with the special phight of the captive auditor, but, instead, indiscriminately sweeps within its prohibitions all "offensive conduct" that disturbs "any neighborhood or person." 1

With these two issues placed to the side, Harlan found that the case presented a smgle remaining issue: whether the state could completcly outlaw the word "fuck," either on the theory that its use is inherently likely to provoke violence, or on the theory that the states, "acting as guardians of public inorahty, inay properly remove this offensive word froin the public vocabulary." 62 As has been shown, ${ }^{63}$ Harlan rejected the violence theory as unsupportable, leaving only the second theory, which Harlan restated as an attempt to inaintain "a suitable level of discourse within the body pohtic." 64 This theory represented state censorship in its purest form: it claimed state power to censor offensive words, even when there was no objection ${ }^{65}$ and no risk of concrete harm. Not only would this censorship apply as fully to

60. 403 U.S. at 21-22.

61. Id. at 22 . Because of Harlan's reference to the "subtlety and complexity of the factors involved," it is difficult to predict what his response to captive audience claims would have been in other situations, such as that in Pacifica.

62. Id. at 22-23.

63. See text accompanying notes $42-44$ supra.

64. 403 U.S. at 23 . It should be clear at this point that this theory is quite different from a captive audience rationale. Under the captive audience rationale, the state can arguably prevent Ann froun using the word "fuck" in a speech to her willing audience, Betty and Charley, in order to protect the sensibilities of Dave, who is unwittingly walking by. Under the public morality theory, the state can take the saine action to "protect" Betty and Charley from hearing language they are willing to hear, but which the state considers unsuitable. Beeause it directly interferes with the relationship between a speaker and a willing audience, regulation based on the public morality rationale is far more paternalistic and conflicts inore directly with first amendment values. See generally Farber, Commercial Speech and First Amendment Theory, 74 Nw. U.L. REv. 372, 404-05 (1979).

65. The importance of the fact that no one objected was brought into focus during oral argument: 
Lenny Bruce speaking to a willing nightclub audience ${ }^{66}$ as it would to Cohen, but presumably it would apply to literary works as well. Despite his willingness to grant the states similar power over erotic literature, ${ }^{67}$ Harlan was reluctant to expand the established exceptions to the usual rule against content censorship. He concluded, for reasons that will be discussed in connection witl Professor Bickel's views, ${ }^{68}$ that

THE COURT: Well, what is there in the record-in testimony-that shows that these words were offensive to any person in that building at that time?

MR. SAUER: There's nothing in the record, Mr. Justice Marshall. We just said "the effect on the average person." As I go back and read Chaplinsky, there's no showing that Major Browerlem, when the man yelled at him "You damn fascist," or "You damn racketeer," was offended by the statement. There's no showing that Major Browerlein was going to react against it.

THE COURT: Well, who in the building was interested in the draft? Does the record show?

MR. SAUER: There's no showing. Even appellant admits the inan was there because just citizens who would be present-

THE COURT: IVell, my great difficulty as to what's the difference between the man whispering something in the corner to somebody, and wearing a jacket that so far as this record shows only one person saw it?

MR. SAUER: No, I beheve three people saw it. There was a S[e]rgeant Spawn. There was someone named Alexander, and there was one other person, I believe, who saw it. THE COURT: Well, was it offensive to them?

THE COURT: Mr. Sauer, may I read from the Settled Statement on appeal? "S[e]rgeant Shauler and Officer Alexander corroborated S[e]rgeant Spawn's testimony as to defendant's presence in the corridor; his wearing of the jacket; his entering the courtroom; and as to the presence in the corridor of women and children." Isn't that the answer?

MR. SAUER: Correct, Mr. Justice Blackmun, yes. I said the record shows that there were other individuals present, as well as three specifically named individuals. Tliere were women and children present in the corridor.

Transcript of Oral Argument, supra note 20, reprinted in 70 P. KURLAND \& G. CASPER at 844-45. This colloquy brings out three interesting points. First, the record does not show that anyone was offended. Second, as far as the record shows, the only people who noticed the jacket were three police officers. Third, at oral argument, at least one Justice was of the view that there was no captive audience problem because the issue would have been the same if Cohen had been "whispering something in the corner to somebody." If the state is to regulate the use of offensive language in a whispered conversation, the state must lave a reason other than a desire to prevent offense to bystanders. Instead, the reason must be a desire to inprove the morals of the participants, or something similar.

66. See generally People v. Bruce, 31 Ill. 2d 459, 202 N.E.2d 497 (1964).

67. See cases cited in note 11 supra. In Cohen, Justice Harlan treated the obscenity cases as involving a special but hinited state power:

[T] his case cannot be said to fall within those relatively few categories of instances where prior decisions have estabhished the power of government to deal more comprehensively with certain forms of individual expression simply upon a showing that sucli a form was employed. This is not, for example, an obscenity case. Whatever else inay be necessary to give rise to the States' broader power to prohibit obscene expression, such expression must be, in some significant way, erotic. Roth $v$. United States, 354 U.S. 476 (1957). It cannot plausibly be maintained that this vulgar allusion to the Selective Service Systen would conjure up such psychic stimulation in anyone likely to be confronted with Cohen's crudely defaced jacket.

403 U.S. at 19-20. Later im the opimion, Justice Harlan stressed that "most situations where the State has a justifiable interest in regulating speech will fall within one or more of the various established exceptions...." Id. at 24.

68. See text accompanying note 109 infra. 
government control over the public vocabulary was intolerable. ${ }^{69}$

It should be clear by now that Harlan's first amendment methodology did not revolve around the simple issue of constitutional protection $^{70}$ for particular conduct. Rather, Harlan first carefully determined what justifications for regulation were properly before the Court and then atteinpted to determine the sufficiency of those particular justifications. The result of this analysis has been imsleading when carelessly used as precedent in later cases. For example, in FCC v. Pacifica Foundation, ${ }^{71}$ the issue was whether a radio station was entitled to play a record containing a nuinber of four-letter words. At first sight, Cohen appears to be powerful precedent on this issue. On closer analysis, lowever, Cohen proves to have little relevance. The Federal Communications Commission's justifications for regulating speech in Pacifica turned on the context of the midafternoon broadcast, whereas Justice Harlan found that none of the possible context-related justifications were properly presented in Cohen. Instead, the issue he did find to be properly presented-and therefore the only issue he decided-was whetler the state, acting as a paternalistic guardian of public norality, could ban the use of certain words in all contexts. Because Pacifica dealt with context and Cohen dealt only with content, Cohen contributes little to the issue presented in Pacifica. ${ }^{72}$

69. From the point of view of judicial craftsmanship, this opimion is most admirable for the precision with which Harlan isolated the essential issue in the case. His elimination of other possible issues was based not only on a sure grasp of the relevant legal tools, see generally Gunther, supra note 4, at 1007 (Harlan's "dissection of state justifications" called "exemplary"), but also on a sound instinct about the crux of the case. Recall that while the record revealed no objections from bystanders in the hall, see note 65 supra, the police pursued Cohen into a courtroom, and even though he had removed the jacket they attempted to have him held in contempt of court. It is hard to perceive this behavior as anything other than the officious intermeddling of self-appointed guardians of public morality. Moreover, Cohen's counsel says that, as far as he knows, the police did not ask Cohen to remove the jacket. Telephone interview with Professor Melville Nimmer, UCLA Law School (Aug. 10, 1979). This reinforces the view that the police were less interested in protecting bystanders than in punishing innnoral speech.

70. Despite the reversal of Cohen's conviction, it still could not be said with any assurance that his conduct was constitutionally immune from prohibiton. See note 55 supra.

71. 438 U.S. 726 (1978).

72. The Court in Pacifica could not avoid the captive audience issue because Pacifica involved an objecting bystander. 438 U.S. at $747 \mathrm{n} .25$. Thus, commentators who find the absence of objection in Cohen an irrelevant difference between the two cases are incorrect. See, e.g., Krattenmaker \& Powe, supra note 10, at $1230 \mathrm{n} .639$. The point is not that a simgle objection is enough to create a strong captive audience claim; rather, the point is that it is difficult to find a captive audience claim at all unless soineone objects.

A case decided a year after Cohen reinforces the view that the Cohen Court did not reach the merits of the context-related justifications for regulating speech. In Rabe v. Washington, 405 U.S. 313 (1972), the Court relied on Cohen im holding that an obscenity conviction could not be upheld on the theory that a film was obscene when shown at a drive-in theatre but not when shown indoors. The state had asserted that it had a special interest im "prohibiting outdoor displays of 
Although Cohen does not resolve all the questions relating to offensive speech, it does answer one basic question: whether the goal of maintaining a minimum quality of public discourse justifies restrictions on offensive speech. Before accepting too readily Justice Harlan's negative answer to this question, however, it is well to consider opposing arguinents.

\section{The Debate on Civility and Restrictions on Speech}

In the abstract, the balance between the values of free speech and public civility is struck all too easily: free speech inust prevail. When confronted with speech that truly offends us, however, we begin to feel the need for a less facile analysis. Cohen's speech is probably not sufficiently offensive to challenge our abstract views on civility and free speech. His underlying inessage was well within the political mainstream. In retrospect, that inessage today probably arouses the syınpathy even of many people whose political views differed at the time. Moreover, Cohen's language has become considerably inore acceptable in what used to be called "polite society."

A nuch tougher test is posed by the facts of Village of Skokie $v$. National Socialist Party ${ }^{73}$ and Collin v. Smith. ${ }^{74}$ These cases arose from the same circuinstances: an attempt by the American Nazi Party to conduct a march in the largely Jewish suburb of Skokie, Illinois. Several thousand survivors of the Third Reich, and nany others whose relatives were inurdered by the Nazis, hive in Skokie. The American Nazis intended to march through town wearing Nazi uniforms and displaying the swastika on armbands and flags. ${ }^{75}$ As the Seventh Circuit observed, we cannot

ignore the certainty that appellees [the Nazis] know full well that, in hight of their views and the historical associations they would bring with them to Skokie, many people would find their demonstration extremely mentally and emotionally disturbing, or the suspicion that such a result may be rehished by appellees. ${ }^{76}$

Although there was reason to fear violence, local officials declined to stop the march on that basis. Instead, they commendably pledged to

sexually frank motion pictures." Id. at 316 . The Court responded that the statute did not give notice that the place where a film was shown was relevant. Consequently, just as the need to maintain decorum near the courts could not be raised to uphold the Cohen conviction, neither could the desire to shield outdoor displays be used to support the conviction in Rabe. See id.

73. 69 Ill. $2 d 605,373$ N.E.2d 21 (1978).

74. 578 F.2d 1197 (7th Cir.), cert. denied, 439 U.S. 916 (1978).

75. For a full statement of the facts, see the Village of Skokie opinion, 69 Ill. $2 d$ at 609-11, 373 N.E.2d at 21-23. Further background on the litigation can be found in Goldberger, Skokie: The First Amendment Under Attack by its Friends, 29 MERCER L. REv. 761 (1978).

76. Collin v. Smith, 578 F.2d at 1200. 
make every effort to protect the Nazis if the march were held.77 Moreoever, there was no captive audience problem. Since the Nazi inarch was well publicized, anyone who would be offended could stay away. ${ }^{78}$ The only remaining basis for cancelling the march or banning the display of swastikas was that the inere existence of such activity was an intolerable affront to our sense of civilized decency.

Both the Illinois Supreine Court and the United States Court of Appeals for the Seventh Circuit were convinced that an affront to our sense of decency did not justify prohibiting the Nazis' march or their display of swastikas. The Seventh Circuit conceded that the Nazis' beliefs are repugnant to our "core values" and to "inuch of what we cherish in civilization."79 Nevertheless, under the first amendment, "there is no such thing as a false idea"; 80 even the Nazis are entitled to compete in the inarketplace of ideas. The Illinois Supreme Court, while admitting that the sight of swastikas is "abhorrent to the Jewish citizens of Skokie"8I and that the inemories evoked are "offensive to the principles of a free nation," 82 concluded with soine reluctance that "it is entirely clear that this factor does not justify enjoinimg defendants' speech."83 Both courts, incidentally, cited Cohen extensively. ${ }^{84}$

It is a tribute to both courts that they ruled as they did despite obvious misgivings about the effects of their decisions. The Skokie cases ought to provoke misgivings. We ought not lightly decide to subject survivors of concentration camps to the nightmare of storm troopers marching through the streets. As a society, inust we tolerate speech that so grievously offends the most basic values of our civilization?

Several years before Skokie, Professor Alexander Bickel presented a forceful arguinent that we should not tolerate this kind of speech. ${ }^{85}$ At soine risk of oversimplification, his basic argument against tolerance may be sumnarized as follows: the necessary premise of the first amendinent is that speech has important consequences. If we believed that "words don't matter, that they inake nothing happen and are too

77. Id. at 1203 n. 10 .

78. In any case, the march was to be held at the city hall on a Sunday afternoon, when few people would normally be present. Id. at 1207 .

79. Id. at 1200 .

80. Id. at 1203 (quoting Gertz v. Robert Welch, Inc., 418 U.S. 323, 339 (1974)).

81. Village of Skokie v. National Socialist Party, 69 Ill. $2 \mathrm{~d}$ at 615,373 N.E.2d at 24.

82. Id.

83. Id.

84. The Collin opinion cites Cohen six times. 578 F.2d at 1201, 1202 (twice), 1204, 1206, 1207 n.18. The Village of Skokie opinion quotes four paragraphs of the Cohen opinion at one point, 69 III. $2 \mathrm{~d}$ at $613-15,373$ N.E.2d at $23-24$, later quotes another paragraph, $i d$. at $615-16,373$ N.E.2d at 24-25, and then cites Cohen again in its concluding paragraph, id. at 619, 373 N.E.2d at 26.

85. Morality of CONSENT 70-71. 
trivial to bother with,"86 then little reason would exist to refrain froin regulating speech that annoys the inajority. Yet, if speech does matter, speech like that of the Nazis must have the capacity for enormous harm. Bickel then addressed and rejected the arguments made by Justices Brandeis and Holmes for tolerating potentially harmful speech. Brandeis, with his usual faith in human nature, argued that further discussion "affords ordinarily adequate protection against the dissemination of noxious doctrine . . ." 87 In other words, bad ideas will not survive exposure to the inarketplace of ideas. Holmes, with his usual toughmindedness, purported not to care: "If im the long run [these] beliefs . . . are destined to be accepted by the dominant forces of the cominunity, the only meaning of free speech is that they should be given their chance and have their way." 88 Bickel rejected Brandeis' optimism. In Bickel's view, to assume that further discussion will necessarily lead to the rejection of false ideas was to ignore the lesson of history that "[d]isastrously, unacceptably noxious doctrime can prevail."89 Nor did Bickel accept Holmes' purported indifference to the final product of the marketplace. Bickel's behef in the inarketplace of ideas was not so strong that he was willing to accept the idea of genocide if enough people came to beheve in it after full discussion. In his view, ideas such as genocide are not entitled to a fair chance to gain inajority support. ${ }^{90}$ In short, Bickel was not willing to ignore the risk that truly horrible ideas inay triumph in the marketplace.

Bickel saw another harin in tolerating unacceptable speech: he found in expressions such as "fuck the draft" a kind of verbal assault on the audience. He beheved also that abusive language creates a moral climate in which antisocial conduct becomes more likely. ${ }^{91}$ As in the case of obscenity, he contended that "what is cominonly read and seen and heard and done intrudes upon us all, wanted or not, for it constitutes our enviroument." 92

To imply that Bickel's appeal was a simple plea for repression,

86. Id. 71 .

87. Whitney v. California, 274 U.S. 357, 375 (1927) (Brandeis, J., concurring), overruled, Brandenburg v. Ohio, 395 U.S. 444 (1969).

88. Gitlow v. New York, 268 U.S. 652,673 (1925) (Holmes, J., dissenting).

89. Morality of CONSENt 72. Professor Kurland apparently slares this view. See Goldberger, supra note 75 , at 770 (quoting a speecls by Kurland).

90. MORALITY OF CONSENT 72, 76-77. In a more recent article, Dean Wellington supported Bickel's view: "Most of us do beheve that the book is closed on some issues. Genocide is an exaunple." Wellington, On Freedom of Expression, 88 YALE L.J. 1105, 1132 (1979).

91. MoRALITY of ConsENT 72-73. "Where nothing is unspeakable, nothing is undoable." Id.

92. Id. 74. For the Supreine Court's response to this arguinent in the obscemity area, see Paris Adult Theatre I v. Slaton, 413 U.S. 49, 59 (1973). See note 17 supra. 
however, would be to misrepresent his views. As always, tension and ambiguity characterized his thoughts. He was keenly aware of the risks created by even the most limited grant of the power of censorship. As a consequence, he sought a workable accommodation rather than a clear resolution of conflicting values. Although his ultimate conclusions were not entirely clear, he seemed inclined toward the following position. ${ }^{93}$ First, he believed that we need to "resist the assertion of absolute claims." 94 In particular, we should not acknowledge a positive right to engage in offensive speech, for to do so is to legitimize it.95 Second, we should control the risks created by restrictive laws tlirougli devices like the vagueness and overbreadth doctrines. ${ }^{96}$ Third, the very existence of restrictive laws, and "occasional but steady enforcenent in aggravated cases," serve the important purpose of providimg visible support for our basic social values. ${ }^{97}$ In sum, Bickel believed that in regulating this area, the law "walks a tightrope, and runs high risks,"98 but that tlre effort is worth it, "[f]or the stakes are high."99

A thouglitful article by Professor Hadley Arkes develops a similar arguinent in the specific context of racial defamation. ${ }^{100}$ Echomg arguinents by Justice Frankfurter ${ }^{101}$ and David Riesman, ${ }^{102}$ Arkes contends

93. I am extrapolating in part from Bickel's conclusions on obscenity, which he viewed as presenting essentially the same issue. Perhaps some of the lack of clarity was due to the evolving nature of his analysis at the time of his death.

94. Morality OF Consent 88.

95. Id. 73 .

96. Id. 78-79. See also id. 87-88.

97. Id. 75 .

98. Id.

99. Id. $75-76$.

100. Arkes.

101. See Beauharnais v. Illinois, 343 U.S. 250 (1952). The present status of Beauharnais is unclear. The opimion has been harshly critized, see, e.g., H. KALVEN, THE NEgRo AND THE FIRST AMENDMENT 1-64 (1965), and some lower courts doubt that it remains good law. See, e.g., Collin v. Smith, 578 F.2d 1197, 1205 (7th Cir.), ccrt. denied, 439 U.S. 916 (1978); Tollett v. United States, 485 F.2d 1087, 1094 n.14 (8th Cir. 1973); Anti-Defamation League of B'nai B'rith v. FCC, 403 F.2d 169, 174 n.5 (D.C. Cir. 1968) (Wright, J., concurring), cert. denied, 394 U.S. 930 (1969). On the other hand, Beauharnais was cited with apparent approval in Paris Adult Theatre. See note 17 supra. The Supreme Court's denial of certiorari in Collin v. Smith, 439 U.S. 916 (1978), leaves the status of Beauharnais highly uncertain.

102. Riesman, Demoeracy and Defamation: Control of Group Libel, 42 Colum. L. REv. 727 (1942). Riesman's conclusion was as follows:

In the more or less denocratic lands, however, the threat of fascism and the chief dangers to freedom of discussion do not spring from the "state", but from "private" fascist groups in the community. These groups try to repress criticism of theinselves, sometimes with the help of government, but more often and more subtly by "private" pressure and coercion. This pressure often takes the form of defamation against opposing weaker groups like "labor", which further weakens these groups in the eyes of the community as a whole-and even in their own eyes. Or the defamation ains to shift to relatively powerless scapegoats-Negroes, Jews, Mexicans-the attacks which might otherwise be nade against the prevailing systein. Usually, both strategies are combmed. In this state 
that defanation creates racial stereotypes that injure mmority groups. ${ }^{103}$ Like Bickel, he believes that some forms of speech constitute assaults as serious as physical assaults. One example he gives is an intimidating (but nonviolent) crowd surrounding the home of the first blacks to move into a white neighborliood. ${ }^{104}$ In his view, governments are morally obligated to protect their citizens froin such conduct. "No government that would call itself a decent government would fail to intervene in these cases . . .."105

Havimg considered the opposing views, we return to Justice Harlan. How well do his arguments stand up to Bickel and Arkes in the context of the Skokie cases? Harlan inakes, in essence, two arguinents for tolerance. The first is that banning offensive inethods of expression is undesirable in itself. When symbols such as the swastika or four-letter words are banned, the speaker's ability to express his emotions and even his ideas is undesirably limited. 106 Further, banning such speecl is inappropriate because the decision to regulate inust be based on subjective judgment; "one inan's vulgarity is another's lyric." 107 Second, even if offensive speech is not to be protected for its own sake, it inust be protected as a necessary side effect of our basic decision to leave control of discourse in the hands of the people rather than the government. ${ }^{108}$ In view of the difficulty of line drawing, we

of affairs, it is no longer tenable to continue a negative policy of protection from the state; such a policy, in concrete situations, plays directly into the liands of the groups whoin supporters of deinocracy need most to fear.

Id. at 779-80. Professor Kalven referred to this as a "brilliant but erroneous prediction about the coming problein of a Fascist exploitation of the American Law of defanation." H. KALVEN, supra note 101, at 233 n.304. On the other hand, the drafters of the Model Penal Code believed that group libel can indeed be "an important instrument in the subversion of denocracy." MODEL Penal Code $\$ 250.7$, Comment 2 (Tent. Draft No. 13, 1961). Note that the Chief Reporter of the Code was Herbert Wechsler.

103. Arkes 292.

104. Id. 309. For a similar expression of the verbal assault idea, see Rosenfeld v. New Jersey, 408 U.S. 901,909 (1972) (Powell, J., dissenting).

105. Arkes 310. See also id. 311. It las been argued that Alexander Meiklejohn would have taken the same position in connection with the Skokie cases. Jones, Alexander Meiklejohn on Skokie, 35 GulLD PRAC. 84, 90-91 (1978). This view finds some support in Meiklejohn's coinments on civility in public discourse:

And, if the interests of a self-governing society are to be served, vituperation which fixes attention on the defects of an opponent's character or intelligence and thereby distracts attention from the question of policy under discussion may be forbidden as a deadly enemy of peaceable assembly. Anyone who persists in it should be expelled from the meeting, and, if need be, the police should give help in getting it done.

Meiklejohn, The First Amendment is an Absolute, 1961 Sup. CT. Rev. 245, 260.

106. Cohen v. California, 403 U.S. at 26.

107. Id. at 25 .

108. To many, the immediate consequence of this freedom may often appear to be only verbal tumult, discord, and even offensive utterance. These are, however, within established limits, in truth necessary side effects of the broader enduring values which the 
cannot afford to open the door to censorship.

As applied to the Nazi march in Skokie, Harlan's first line of argument seems misplaced. While one man's vulgarity may be another man's lyricism, this kind of relativism is misguided when apphed to the swastika. Rejectimg the swastika is not on the same level of subjective taste as disliking garlic, if one has the slightest behef $m$ the existence of moral standards. Perhaps banning the swastika limits expression of an idea. Bickel is surely right, however, that there is no affirmative societal interest $\mathrm{m}$ encouraging the uninhibited propogation of that idea. $\mathrm{He}$ is surely also right that genocide is not an issue on which we are prepared to abide by the results of a referenduin. While the first amendment may give some protection to the expression of einotion, a person's desire to express vicious racial prejudices deserves no solicitude on our part. If this speech is to be protected, in short, the reason cannot be our concern that the Nazis nnight lose the opportunity to impart their message and convert new disciples.

Justice Harlan is on stronger ground in arguing that this speech, although worthless, must be tolerated because of the risks created by suppression. An attempt to purge public discourse of everything offensive and obnoxious undoubtedly would drastically impair the "robust and uninhibited" public debate we value. ${ }^{109}$ There is also force $\mathrm{m}$ Harlan's argument that it is risky to make any exceptions on this point, lest there be no primcipled stopping place. Fimally, he is, one hopes, justified in his faith that our society is strong enough to shrug off the side effects of allowing even the most debased inessages their place in the market.

Perhaps Harlan's argument is all the justification for tolerance we should require. Yet somehow it does not fully satisfy. It is true that if we began to make exceptions for especially horrible speech we would have to draw the line somewhere. Still, much of the law consists of rough but workable line drawing. In this situation, the line could be drawn generously enough to allow speech with any conceivable merit. Justice Harlan may be right that the risk, albeit small, is just not worth taking, but this is a rather negative reason for protecting speech. It rejects the practicability, but not the desirability, of suppression. To permit speech we detest would be more palatable if we beheved that doing so served some positive purpose, rather than simply the negative

process of open debate permits us to achieve. That the air may at times seem filled with verbal cacophony is, in this sense, not a sign of weakness but of strength.

Id. at 24-25.

109. See Watts v. United States, 394 U.S. 705, 708 (1969); New York Times v. Sullivan, 376 U.S. 254, 269-70 (1964); Terminiello v. Chicago, 337 U.S. 1, 4-5 (1949). 
one of preventing the shghtest leak in the first ainendment dike.

Part of Professor Arkes' argument for suppressing truly offensive speech inadvertently suggests a positive reason for permitting it. In the course of discussing the "group libel" case of Beauharnais $v$. Illinois, ${ }^{10}$ Professor Arkes contrasts the vicious racial slurs involved in that case with Dr. Jenson's heavily qualified, scholarly writing on racial inferiority, writing Arkes clearly would not atteinpt to ban. ${ }^{11}$ Would it be desirable as a matter of policy to limit expression of belief in racial inferiority to respectable scholarly discussions, assuming of course that all other speech was left entirely unaffected? There is at the outset soinething reassuring and attractive about the notion of limiting discussion of such ideas to the pleasant, civilized atmosphere we associate with academia, while ridding ourselves of crude, veheinent expressions of racism. Yet on closer examination there is also something seriously wrong with this idea. Limiting expression of racist views to the calm, heavily qualified statements of scholars would give a completely inisleading view of racist thinking. The truth is that racisin in our society is far more often characterized by the ugliest of einotions. If many of its expressions are ugly, that is because the attitudes behind those expressions are ugly. The inost obnoxious expressions of racisin confront us with the offensiveness of the speakers and their ideas. We obtain an important truth from these speakers, although it is not a truth they mean to convey.

In the Skokie cases, if we take away the swastika, we take away the most vivid reminder of just how offensive the Nazis are. We need to be reminded of the consequences of their kinds of "ideas." We also need to be reminded that the Nazis are not just another group of harmless cranks: their views have a deadly potential that we inust not be allowed to forget. In short, as in the case of racist invective, to reduce the ugliness of the Nazis' speech would only conceal the real ugliness, the uglimess of their ideas. That truth is too important to suppress merely

110. 343 U.S. 250 (1950). Beauharnais is discussed in notes 17 \& 101 supra.

11. Because of the pivotal inportance of this passage, full quotation seems appropriate:

The comparison, however, is not fully satisfying. There are important differences that are not to be discounted in the way the material is treated in the hands of a scholar and the way it is used by a Beauharnais. Scholars may vary widely in their degree of scholarly care, but they are almost universally cautious about qualifymg their remarks, and if for no better motive than to guard themselves against obvious criticism, they can usually be depended on to say soinething about the himits of generality in the analyses they are offering. With the inaterial involved in Beauharnais, a scholar would be likely to have warned that the data he was reporting about blacks described the characteristics of an aggregate; that it was hazardous to draw inferences about individuals from the statistical profile of a population; and that there was of course some overlap among populations, so that there were classes of whites who had higher crime rates than blacks as a group, and many blacks who had never been implicated in a crime.

Arkes 300 . 
to maintain our mental equanimity.

What of Cohen v. California? For the militarist, perhaps Cohen stands on all fours with the Skokie cases. To allow Cohen to use offensive language reinforces the offensiveness of his views. It also reveals the link between those views and rebellion against other American norms. For the rest of us, Cohen's inessage was within the bounds of the legitimately thinkable, and his use of strong language accurately reflected his views. After all, few things are more offensive than an unjust war. ${ }^{12}$

In short, offensiveness is often an important part of the speaker's message. Use of offensive language reveals the existence of soinething offensive and ugly, whether in the situation described by the speaker or in the speaker's mind itself. In either event, the language reveals an important though unpleasant truth about the world. Suppressing this language violates a cardinal primciple of a free society, that truths are better confronted than repressed. As long as we hive in an ugly world, ugly speech must have its forum. ${ }^{113}$ We cannot expect to have, nor should we require, true civility in discourse until we achieve civility in society.

112. In Cohen, there may be an additional reason for permitting the speech. In a democracy, given the government's lack of any power to coerce respect from its citizens, see Street $v$. New York, 394 U.S. 576, 593 (1969), there may be a special privilege to use abusive, offensive language with respect to the government. See generally Coulton v. Kentucky, 407 U.S. 104, 122 (1972) (Douglas, J., dissenting). In this respect, offensive speech like that used in Cohen is like seditious libel, but is the converse of group libel. As Riesman has noted, in many ways, group libel is the reverse image of seditious libel. What would be seditious libel if directed against those in power is group libel when directed agamst powerless mimorities. See Riesman, supra note 102, at 734-39, 779-80. See also H. KALVEN, supra note 101, at 1-64 (linking group libel and seditious libel).

113. This phrasing is chosen dehberately. Spcech of this kind must have a forum in which it can be presented. It does not necessarily follow that every forum should be open to such speech, if there are reasons for exclusion such as captive audience problems. Thus, this analysis does not require that courts void context-related bans such as that in Pacifica.

There is a further reason why this analysis does not apply to Pacifica. In Pacifica, to the extent that the offensive speech was "about" anything, it was about the undesirability of the Federal Communications Commission ban of indecent speech. Pacifica Foundation v. FCC, 556 F.2d 9,33 (D.C. Cir. 1977), rev'd, 438 U.S. 726 (1978). On the theory explained in the text, it might be argued that this speech served the useful function of confronting the audience with the potential offensiveness of the speaker's point of view concerning the right to use indecent language. But if we assume that the broadcast was protected, the audience cannot do anything about the issue anyway. If people are repelled by the Nazis, they can oppose their program. If people are repelled by the monologue in Pacifica, there is nothing for them to oppose but re-broadcasting the monologue itself. Because of this element of circularity, the analysis presented in the text is inapplicable to the situation presented in Pacifica. The necessary preinise is that the offensiveness of the speech reveal something about some other issue, not simply about the speech itself as in Pacifica. 


\section{CONCLUSION}

Justice Harlan narrowed the issues in Cohen to a single question: whether the state has the power to upgrade public discourse by banning offensive speech. He concluded that this power is lacking, a conclusion easy enough to accept in Cohen, but more difficult in cases like Village of Skokie and Collin, where the speech is inore offensive and inore clearly worthless. In this context, Professor Bickel's arguments become harder to refute. Yet there is much to be said for Harlan's counterarguinent that the benefits to be gained outweigh the risks created by even the inost limited censorship.

The last portion of this Essay has attempted to bolster Harlan's argument with an additional rationale, that the most highly offensive forms of expression commumicate an important truth about the offensiveness of the speaker's message. They have a place in the marketplace of ideas because they help the marketplace reject false, ugly ideas by revealing them for what they are. Acceptance of this rationale depends, of course, on a basic confidence in the ability of the people to understand and to act upon what they read and liear. It is this confidence in the American people that Justice Harlan so eloquently expressed in his Cohen opinion.

This Essay has stressed throughout the limits on the holding in Cohen. While Cohen says that offensive speech may not be barmed outright, it says httle about when such speech can be banned in particular contexts. It offers only limited guidance for determining to what extent government can protect people from involuntary exposure to offensive forms of expression. It does not even assure us that Paul Cohen was entitled to wear his jacket in the courthouse corridor. It does, however, establish one very important primciple: the government is not entitled to assume the role of moral guardian and to set the standards of acceptable discourse. ${ }^{114}$ Estabhishment of that primciple is an enduring contribution to our legal heritage.

114. Another way of stating the Cohen holding is that the government is not entitled to jail people as part of an educational prograin to inprove their vocabularies. Even without the first amendment, the Court might find a way to void such perverse legislation. See generally Carey v. Population Control Servs., 431 U.S. 678, 713-16 (1977) (Stevens, J., concurring in part and concurring in the judgment). See also O'Connor v. Donaldson, 422 U.S. 563, 575 (1975) (citing Cohen for the proposition that public intolerance of eccentric behavior cannot justify incarceration). 
HeinOnline -- 1980 Duke L.J. 3041980 